\title{
Low Elderly Participation in Non-Small Cell Lung Cancer Clinical Trials
}

\author{
Amy L Cummings ${ }^{1^{*}}$, Melody Mendenhall ${ }^{2}$ and Jonathan W Goldman ${ }^{2}$ \\ ${ }^{1}$ Division of Medicine, David Geffen School of Medicine at the University of California, Los Angeles, USA \\ 2Division of Medicine, Hematology \& Oncology, David Geffen School of Medicine at the University of California, Los Angeles, USA
}

"Corresponding author: Amy L Cummings, UCLA Medical Center, 2020 Santa Monica Blvd, Suite 200, Santa Monica, CA 90404, United States, Tel: 2547241172; Email: alcummings@mednet.ucla.edu

Rec date: Aug 19, 2015; Acc date: Aug 30, 2015; Pub date: Sep 1, 2015

Copyright: (c) 2015 Cummings AL, et al. This is an open-access article distributed under the terms of the Creative Commons Attribution License, which permits unrestricted use, distribution, and reproduction in any medium, provided the original author and source are credited.

\begin{abstract}
Background: Lung cancer, with a median age at diagnosis of 70 years, is the current leading cause of cancer mortality in the United States. A lack of elderly enrollment in lung cancer clinical trials, however, has led to difficulty establishing elderly guidelines for treatment and has been highlighted by the Institute of Medicine and the American Society of Clinical Oncology as a key area for improvement. While there have been few elderly-specific clinical trials investigating chemoradiotherapy in lung cancer, there have been no elderly-specific trials investigating targeted therapy or immunotherapy and little is known about elderly outcomes with these agents.
\end{abstract}

Methods: PubMed was queried for phase I clinical trials involving non-small cell lung cancer (NSCLC) in English in the past five years. Of these 192 studies, 49 investigated targeted therapy and/or immunotherapy without protocolized chemoradiotherapy. These articles were reviewed and assessed based on age demographics and outcomes.

Results: Twelve percent of studies had a mean/median age of 65-69 years; no studies had a mean/median age of 70 years or greater. Of the seven studies with published information on age distribution, only four had information regarding the percentage of participants 70 years or older, which ranged from $8-33 \%$ and was limited by a total sample size of 15-26. The few studies that published information on age-specific outcomes suggested that targeted therapy and immunotherapy in the elderly may be as well tolerated and have similar treatment outcomes, but were limited by the small number of elderly participants in these trials.

Conclusion: Additional research involving elderly enrollment and outcomes in NSCLC clinical trials is warranted. Increased recruitment of the elderly in clinical trials and publication of elderly-specific outcomes in lung cancer research is key to improving treatment guidelines in this field.

Keywords: Elderly; Non-small cell lung cancer; Clinical trial; Targeted therapy; Immunotherapy

\section{Introduction}

Cancer in the aging population has attracted increasing attention in the United States related both to the growing percentage of individuals over the age of 65 years as well as the increased vulnerability of this aging population to morbidity and mortality [1-4]. Lung cancer, of which non-small cell lung cancer (NSCLC) comprises 85\% [5], is an area of particular interest. Two-thirds of all new cases of lung cancer are diagnosed in those 65 years or older [5], but elucidation of elderlyspecific NSCLC guidelines has been problematic [6,7]. There simply is not enough data on the treatment of elderly NSCLC patients to form comprehensive evidence-based recommendations. This situation is not unique to NSCLC, and both the Institute of Medicine (IoM) and American Society of Clinical Oncology (ASCO) have issued position statements urging cancer researchers to improve the evidence for treating older adults $[1,2]$.

ASCO, in a position statement published online ahead of print July 2015 , identified inclusion of elderly patients in clinical trials a key point of action [2]. Patients over the age of 70 have previously accounted for only $10 \%$ of participation in clinical trials [8], and although more recent data has suggested this may be improving, overall enrollment of the elderly in clinical trials and NSCLC clinical trials has continued to be unrepresentative [9-11]. Potential reasons for suboptimal clinical trial recruitment and enrollment are varied, including perceived toxicity risk, increased comorbidities, difficulty with functional assessment, concerns regarding physiologic changes with senescence, socioeconomic and financial disparities, and age bias on the part of researchers, patients, and their families [1]; yet there have been no findings to support an age limit to the benefits of treatment [6]. A 2005 review of chemoradiotherapy NSCLC trials supported the elderly suffer low rates of severe adverse events with no statistically significant differences in survival compared to their younger peers [12]. Nevertheless, targeted therapy and immunotherapy, agents of considerable interest in current NSCLC treatment, remain an area of uncertainty for elderly patients $[7,13]$. As of July 2015, there had been no elderly-specific trials with targeted therapy, immunotherapy, or a combination of these therapies with chemotherapy or radiation and few elderly-specific outcomes published in large, prospective, randomized trials with these agents.

\section{Methods}

The PubMed database was queried for Medical Subject Headings (MeSH) including NSCLC/therapy and "Phase I" or "Phase 1". Limits 
Citation: Cummings AL, Mendenhall M, Goldman JW (2015) Low Elderly Participation in Non-Small Cell Lung Cancer Clinical Trials . Gerontol

Page 2 of 4

were set to clinical trials in English in the past 5 years with human subjects. A total of 192 studies met these criteria, which were further limited to 155 based on exclusion of descriptive, retrospective, mislabeled and observational/characterization studies, as well as those not directly related to treatment of NSCLC. Of these studies, 49 included treatment with targeted therapy or immunotherapy without protocolized chemoradiotherapy (see Appendix). These studies were assessed based on target population, intervention, sample size, age demographics, and outcomes, including grade 3-4 toxicities. When available, information on treatment completion (TC), overall response rate (ORR), progression-free survival (PFS), and overall survival (OS) were included as well as any differences in patients 70 years and above (elderly) and 85 years and above (extreme elderly).

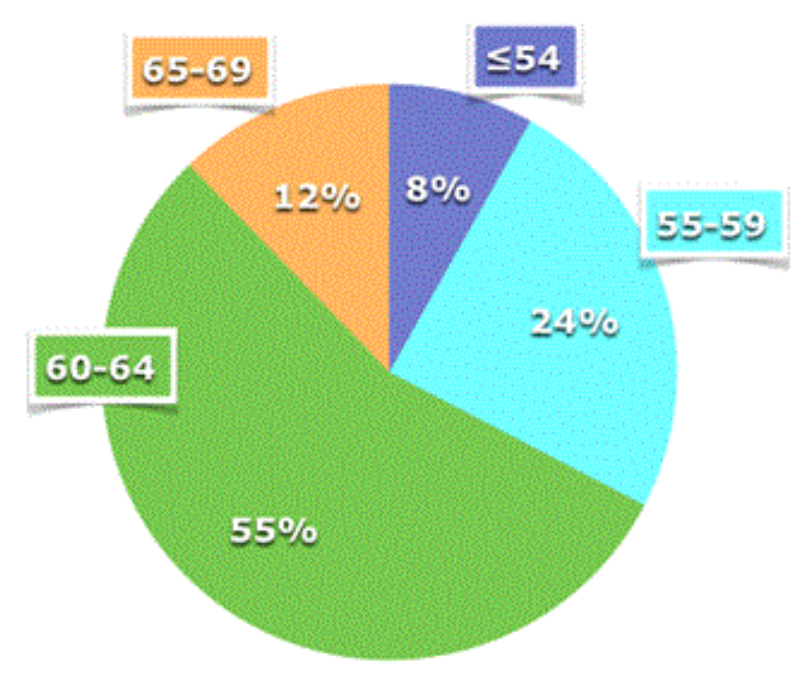

Figure 1: Distribution of Mean/Median ages (in years).

\section{Results}

Approximately two-thirds of the studies meeting inclusion criteria involved advanced NSCLC; the remaining studies evaluated two or more solid malignancies. Targeted therapy was the focus of $70 \%$ of the studies, $24 \%$ involved immunotherapy, $6 \%$ involved other agents. Sample size ranged from 5-495 participants: $28 \%$ had less than 20 participants, $38 \%$ had $20-49$ participants, $16 \%$ had 50-99 participants, and $18 \%$ had over 100 participants. The mean/median age ranged from 46-69 years. Twelve percent of the trials had mean/median ages 65-69 years, 54\% 60-64 years, 24\% 55-59 years, and $8 \%$ less than 54 years (Figure 1).

Seven studies included sufficient information to calculate a percentage of participants above the age of 70 years, which ranged from $8-33 \%$ (Table 1). Percentages $>17$ were in studies with 15 participants or less. Three additional studies provided information regarding the percentage of participants over the age of 60 and 65 years (Table 1). Twenty percent of trials had at least one patient over the age of 85 years, $12 \% 80-84$ years, $43 \% 75-79$ years, $10 \% 70-74$ years; $8 \%$ had participants younger than 70 years (Figure 2) [14,15].

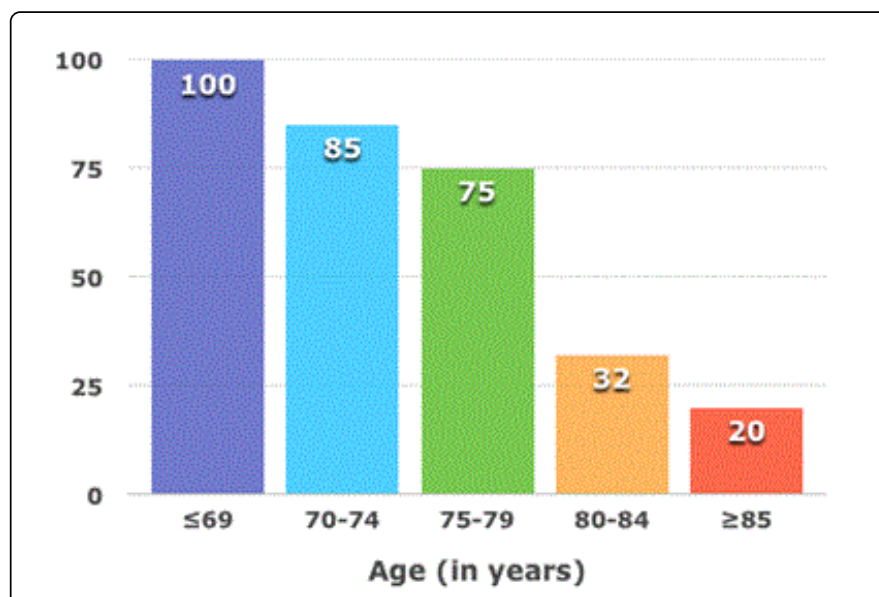

Figure 2: Percentage of Studies including atleast one participant in each age category.

Six percent of studies did not publish this information. Only three studies had age limits to enrollment at 70, 74, and 75 years; these were all published prior to 2012. The maximum age of an enrolled participant was 94 years [16]; Garon [16] included a 93 year-old [17]. Of the ten studies that included a participant 85 years or older, four were immunotherapy studies, six targeted therapy studies, and one other - kahalide F. Of the participants over the age of 70 years with published gender, seven out of nine were men.

\begin{tabular}{|c|c|c|c|c|c|c|c|}
\hline $\begin{array}{l}\text { Lead author, } \\
\text { Year, }\end{array}$ & Population & Intervention & Sample size & Meant age $(y)$ & Max age (y) & $\geq 70 y^{*}(\%)$ & $\geq 85$ y (\%) \\
\hline Wheler [14] 2013 & NSCLC stage III-IV & Cetuximab with Eriotinib & 20 & 66 & 82 & NA ( $\geq 60$ y:60) & 0 \\
\hline Suzuki 2013 & NSCLC stage III-IV & $\begin{array}{l}\text { Peptide Vaccines VEGFR } \\
1 / 2 \text {, URLC10, TTK protein } \\
\text { kinase }\end{array}$ & 15 & 58 & 69 & NA ( $\geq 65$ y:27) & 0 \\
\hline Camidge 2012 & $\begin{array}{l}\text { NSCLC stage III-IV } \\
\text { w/ALK mutation }\end{array}$ & Crizotinib & 143 & 52 & 86 & NA ( $\geq 65$ y:14) & $\mathrm{NA} \$,>1$ \\
\hline Brunsvig 2011 & $\begin{array}{l}\text { NSCLC stage IIIA- } \\
\text { IV }\end{array}$ & $\begin{array}{l}\text { Telomearse peptide } \\
\text { Vaccination }\end{array}$ & 26 & 58.5 & 76 & 8 & 0 \\
\hline Sakamoto 2011 & Advanced NSCLC & $\begin{array}{l}\text { Zoledronate-expanded } ¥ \bar{\delta} \\
\text { T-cells }\end{array}$ & 15 & 67 & 85 & 33 & 7 (all male) \\
\hline Iliopoulou 2010 & $\begin{array}{l}\text { NSCLC stage IIIB- } \\
\text { IV }\end{array}$ & $\begin{array}{l}\text { Allogeneic natural killer } \\
\text { cells }\end{array}$ & 15 & 65 & 75 & 20 & 0 \\
\hline
\end{tabular}


Citation: Cummings AL, Mendenhall M, Goldman JW (2015) Low Elderly Participation in Non-Small Cell Lung Cancer Clinical Trials . Gerontol

Page 3 of 4

\begin{tabular}{|l|l|l|l|l|l|}
\hline Um 2010 & NSCLC stage III-IV & Dendritic cell vaccine & 15 & 60 & 13 \\
\hline $\begin{array}{l}\text { *Listed chronologically. tWhen mean age is not available, median age is substituted as denoted by whole number without decimal point. 'If information is available for } \\
\text { an age set other than } \geq 70 \text { years, it is designated NA with the appropriate age set and corresponding percentage in parentheses. All values expressed as percentages } \\
\text { rounded to the nearest percentage. \$Specific percentage not published, but given the Max age of trial, it was determined to be >1. All values expressed as } \\
\text { percentages rounded to the nearest percentage. }\end{array}$ \\
\hline
\end{tabular}

Table 1: Percentages of Elderly Patients in Targeted therapy, Immunotherapy NSCLC Phase I Clinical trials.

\begin{tabular}{|c|c|c|c|c|c|c|c|c|c|}
\hline $\begin{array}{l}\text { Lead } \\
\text { author, } \\
\text { year }\end{array}$ & Design' & Sample characteristics' & Intervention & $\begin{array}{l}\text { Sample } \\
\text { size }\end{array}$ & $\begin{array}{l}\text { Mean• } \\
\text { age }(y)\end{array}$ & $\begin{array}{l}\text { Max } \\
\text { age } \\
(y)\end{array}$ & $\geq 70 y$ & Outcomes & $\begin{array}{l}\text { Elderly } \\
\text { Outcomes' }\end{array}$ \\
\hline \multirow[t]{2}{*}{$\begin{array}{l}\text { Sukzuki } \\
2013\end{array}$} & \multirow[t]{2}{*}{$\begin{array}{l}\text { Single center, } \\
\text { open-label, } \\
\text { single arm }\end{array}$} & 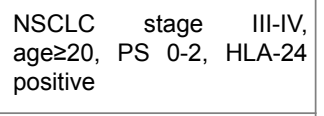 & \multirow{2}{*}{$\begin{array}{l}\text { Peptide vaccines } \\
\text { VEGFR1/2, } \\
\text { URLC10, TTK } \\
\text { protein kinase; } \\
\text { weekly injections }\end{array}$} & \multirow[t]{2}{*}{15} & \multirow[t]{2}{*}{58} & \multirow[t]{2}{*}{69} & \multirow[t]{2}{*}{$0 \geq 65$ y:4 } & \multirow{2}{*}{ 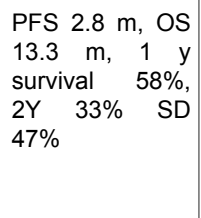 } & \multirow[t]{2}{*}{$\begin{array}{l}\text { SD } 50 \% \text { (T-cell } \\
\text { responders), PD } \\
50 \% \quad \text { (minimal } \\
\text { responders) }\end{array}$} \\
\hline & & $\begin{array}{l}\text { Exclusion: autoimmune } \\
\text { disease, systemic steroid } \\
\text { use }\end{array}$ & & & & & & & \\
\hline \multirow[t]{2}{*}{$\begin{array}{l}\text { Camidge } \\
2012\end{array}$} & \multirow[t]{2}{*}{$\begin{array}{l}\text { Multicenter, } \\
\text { open-label, } \\
\text { single arm }\end{array}$} & $\begin{array}{l}\text { NSCLC stage III-IV w/ALK } \\
\text { mutation, age } \geq 18 \text {, PS } 0-2\end{array}$ & \multirow[t]{2}{*}{$\begin{array}{l}\text { Crizotinib } 250 \mathrm{mg} \\
\text { po BID 28-day } \\
\text { cycle }\end{array}$} & \multirow[t]{2}{*}{143} & \multirow[t]{2}{*}{52} & \multirow[t]{2}{*}{86} & \multirow[t]{2}{*}{$N A \geq 65 y: 20$} & \multirow[t]{2}{*}{$\begin{array}{lr}\text { PFS } 9.7 & \text { m } 1 \text { y } \\
\text { survival } & 75 \% \\
\text { OOR } 61 \% & \end{array}$} & \multirow[t]{2}{*}{ OOR $65 \%$} \\
\hline & & $\begin{array}{lr}\text { Exclusion: } & \text { CNS } \\
\text { involvement } & \text { unless } \\
\text { treated/stable>2 } & \text { wks, } \\
\text { prolonged QT } & \end{array}$ & & & & & & & \\
\hline \multirow{3}{*}{$\begin{array}{l}\text { Takahashi } \\
2012\end{array}$} & \multirow{3}{*}{$\begin{array}{l}\text { Single center, } \\
\text { open-label, dose } \\
\text { escalation } 3+3\end{array}$} & Advanced solid tumors, & \multirow{3}{*}{ 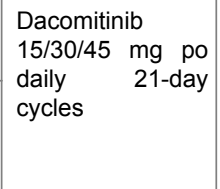 } & \multirow[t]{3}{*}{13} & \multirow[t]{3}{*}{63.2} & \multirow[t]{3}{*}{71} & \multirow[t]{3}{*}{ NA } & \multirow{3}{*}{$\begin{array}{l}\text { PR } 8 \%, \text { SD } 69 \% \\
\text { NSCLC } \\
50 \%\end{array}$} & \multirow[t]{3}{*}{ NSCLC DC $80 \%$} \\
\hline & & age $\geq 20$ and $\leq 75$, PS $0-1$ & & & & & & & \\
\hline & & $\begin{array}{lr}\text { Exclusion: } & \text { CNS } \\
\text { metastases, } & \text { corneal } \\
\text { abnormalities } & \end{array}$ & & & & & & & \\
\hline \multirow[t]{2}{*}{$\begin{array}{l}\text { Brunsvig } \\
2011\end{array}$} & \multirow{2}{*}{$\begin{array}{l}\text { Single center, } \\
\text { open-label, dose } \\
\text { escalation two } \\
\text { cohorts }\end{array}$} & $\begin{array}{l}\text { NSCLC stage IIIA-IV, age } \\
\geq 18 \text { and } \leq 75 \text {, PS } 0-1\end{array}$ & \multirow{2}{*}{ 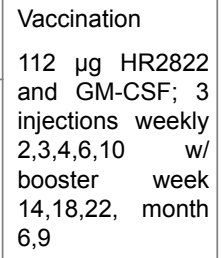 } & \multirow[t]{2}{*}{26} & \multirow[t]{2}{*}{57.8} & \multirow[t]{2}{*}{76} & \multirow[t]{2}{*}{2} & \multirow{2}{*}{$\begin{array}{l}\text { At } 8 \text { years: } \\
\text { ORR } 31 \% \\
\text { TC } 54 \%\end{array}$} & \multirow{2}{*}{$\begin{array}{l}\text { At } 8 \text { Years: } \\
\text { ORR } 0 \% \text {, } \\
\text { TC } 100 \% \\
\text { (Immune } \\
\text { responder OS } \\
\begin{array}{ll}19 \\
m \text {, non } 3.5\end{array} \\
\text { m) }\end{array}$} \\
\hline & & 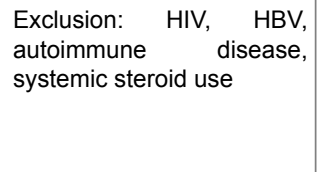 & & & & & & & \\
\hline \multirow[t]{2}{*}{$\begin{array}{l}\text { Sakamoto } \\
2011\end{array}$} & \multirow[t]{2}{*}{$\begin{array}{l}\text { Single center, } \\
\text { open-label, } \\
\text { single arm }\end{array}$} & $\begin{array}{l}\text { NSCLC stage III-IV, } \\
\text { age } \geq 20, \text { PS } 0-2, \text { y } \delta \text { T-cells } \\
100 X D 10 \text { vs } D 1 \text { culture }\end{array}$ & $\begin{array}{l}\text { Expanded yठ T- } \\
\text { cells IV biweekly } \\
\text { for } 6 \text { infusions }\end{array}$ & 15 & 67 & 85 & $5 \geq 85 \mathrm{y}: 1$ & $\begin{array}{l}\text { PFS } 4.2 \mathrm{~m}, \text { OS } \\
19.6 \mathrm{~m} \text { SD } 40 \% \\
\text { Toxicities: }\end{array}$ & $\begin{array}{l}\text { SD } 40 \% \\
\text { Toxicities: GGT } \\
\text { increased } 0 \%\end{array}$ \\
\hline & & $\begin{array}{l}\text { Exclusion: anti-adult T-cell } \\
\text { leukemia-associated } \\
\text { antigen positivity, HIV, } \\
\text { autoimmune disease, } \\
\text { systemic steroid use }\end{array}$ & & & & & & $\begin{array}{l}\text { Increased GGT } \\
7 \% \\
\text { Lung infection } \\
7 \% \\
\text { Pneumonitis } 7 \%\end{array}$ & $\begin{array}{l}\text { Ling infection } \\
20 \% \\
\text { Pneumonitis } 0 \%\end{array}$ \\
\hline $\begin{array}{l}\text { Abbreviatio } \\
\text { progressive } \\
\text { rate. 'All tria } \\
\text { and exclusi } \\
\text { agents, do } \\
\text { allergies to } \\
\text { denoted by } \\
\text { years and } \\
\text { to those } 65\end{array}$ & $\begin{array}{l}\text { R w complete re } \\
\text { ease. PFS w med } \\
\text { e prospective, ph } \\
\text { riteria. It should b } \\
\text { lave severe active } \\
\text { study drug(s), an } \\
\text { le nurnber witho } \\
\text { it is listed with th } \\
\text { s and older. }\end{array}$ & $\begin{array}{l}\text { esponse. DC w disease contro } \\
\text { lian progression-free survival. } \\
\text { hase I trials published in Englis } \\
\text { pe assumed included patients } \\
\text { e infections or severe oo-moro } \\
\text { hd have the ability to absorb a } \\
\text { ut decimal point. !Refers to nu } \\
\text { he age range followed by a col }\end{array}$ & $\begin{array}{l}\text { D (CR+PR+SD). NA } \\
\text { PR - partial respons } \\
\text { sh in the past } 5 \text { years } \\
\text { have measurable di } \\
\text { oid conditions includi } \\
\text { any oral medication } \\
\text { umber of participants } \\
\text { lon. All values expre }\end{array}$ & $\begin{array}{l}\text { not availa } \\
\text { se. PS }-E C \\
\text { s }(7 / 14 / 201 \\
\text { isease, are } \\
\text { ing cardiac } \\
\text { without lin } \\
\text { s over age } \\
\text { ssed as pe }\end{array}$ & $\begin{array}{l}\text { ORR w } \\
\text { S Perforn } \\
/ 15 / 2015 \\
\text { t pregna } \\
\text { patic, or } \\
\text { tions. Wh } \\
70 \text { years } \\
\text { entages } r\end{array}$ & $\begin{array}{l}\text { erall } r \\
\text { nce St } \\
\text { List is } \\
\text { or bre } \\
\text { nal dis } \\
\text { mear } \\
\text { Vhen i } \\
\text { nded } t\end{array}$ & $\begin{array}{l}\text { sonse rate }(C \\
\text { s. SO } \cdot \text { stable } \\
\text { exhaustive } \\
\text { ieeding, have } \\
\text { se, have ade } \\
\text { ge is not ava } \\
\text { liation is avai } \\
\text { he nearest pe }\end{array}$ & $\begin{array}{l}\text { R+PR). OS w ove } \\
\text { disease. TC - trec } \\
\text { and includes most } \\
\text { not had recent tre } \\
\text { quate organ functio } \\
\text { ilable, median age } \\
\text { lable for an age ra } \\
\text { rcentage.iDenotes }\end{array}$ & $\begin{array}{l}\text { rall survival. PD w } \\
\text { atment con:pleb:in } \\
\text { pertinent inclusion } \\
\text { eatment with other } \\
\text { n, have no known } \\
\text { is substituted as } \\
\text { nge other than } 70 \\
\text { outcomes related }\end{array}$ \\
\hline
\end{tabular}

Table 2: Targeted therapy, immunotherapy phase I Non-small cell lung cancer (NSCLC) clinical trials including elderly outcomes.

The only studies that provided sufficient information to correlate outcomes with age included Suzuki, Camidge, Takahashi, Brunsvig, and Sakamoto (Table 2). Three of these studies evaluated immunotherapy. All studies except for Camidge included 26 patients or less. Camidge found that crizotinib in ALK rearranged NSCLC had similar ORR for all patients and those over the age of 65 years $(61 \%$ vs. $65 \%$, respectively). Suzuki showed that peptide vaccines resulted in similar SD in all patients and those over the age of 65 years $(47 \%$ vs 
50\%). Takahashi suggested improved outcomes with dacomitinib for disease control in those over the age of 65 years ( $80 \%$ vs $50 \%)$, but was limited by a sample size of 13 . Brunsvig found that elderly patients completed telomerase peptide vaccination on par with all patients ( $100 \%$ vs $75 \%)$, but enrolled only 2 patients over the age of 70 Sakamoto suggested that infusion of in vitro expanded T-cells led to similar rates of SD in those above and below the age 70 years $(40 \%$ vs $40 \%$ ) and was similarly well tolerated; one of 5 patients over the age of 70 had an adverse event; a patient over the age of 85 years had no adverse events.

\section{Conclusion}

These findings support that elderly participation in phase I targeted therapy and immunotherapy NSCLC clinical trials is unrepresentative. Data regarding elderly outcomes with NSCLC targeted therapy and immunotherapy is severely limited by low elderly participation rates and omission of elderly-specific data publication. This review supports the IoM and ASCO position statements in that elderly participation and data in clinical trials deserves further attention. Increased recruitment of the elderly in clinical trials and publication of elderlyspecific outcomes in lung cancer research is key to improving treatment guidelines in this field.

\section{References}

1. Levit L, Balogh E, Nass S, Ganz PA (2013) Delivering High-Quality Cancer Care: Charting a New Course for a System in Crisis. Washington (DC).

2. Hurria A, Levit LA, Dale W (2015) Improving the Evidence Base for Treating Older Adults With Cancer: American Society of Clinical Oncology Statement. J Clin Oncol.

3. Yancik R, Ershler W, Satariano W, Hazzard W, Cohen HJ, et al. (2007) Report of the national institute on aging task force on comorbidity. J Gerontol A Biol Sci Med Sci 62:275-80.

4. Weir HK, Thompson TD, Soman A, Moller B, Leadbetter S (2015) The past, present, and future of cancer incidence in the United States: 1975 through 2020. Cancer.

5. Howlader NNA, Krapcho M, Garshell J, Miller D, Altekruse SF, et al. (2015) SEER Cancer Statistics Review, 1975-2012, National Cancer Institute.
6. Pallis AG, Gridelli C, van Meerbeeck JP (2010) EORTC Elderly Task Force and Lung Cancer Group and International Society for Geriatric Oncology (SIOG) experts' opinion for the treatment of non-small-cell lung cancer in an elderly population. Ann Oncol 21: 692-706.

7. Gajra A, Jatoi A (2014) Non-small-cell lung cancer in elderly patients: a discussion of treatment options. J Clin Oncol 32: 2562-9.

8. Begg CB, Carbone PP (1983) Clinical trials and drug toxicity in the elderly. The experience of the Eastern Cooperative Oncology Group. Cancer 52:1986-92.

9. Gridelli C, Maione P, Colantuoni G, Rossi A (2002) Chemotherapy of non-small cell lung cancer in elderly patients. Curr Med Chem 9:1487-95.

10. Hutchins LF, Unger JM, Crowley JJ, Coltman CA, Albain KS (1999) Underrepresentation of patients 65 years of age or older in cancertreatment trials. N Engl J Med 341: 2061-7.

11. Firat S, Byhardt RW, Gore E (2010) The effects of comorbidity and age on RTOG study enrollment in Stage III non-small cell lung cancer patients who are eligible for RTOG studies. Int J Radiat Oncol Biol Phys 78: 1394-9.

12. Jatoi A, Hillman S, Stella P (2005) Should elderly non-small-cell lung cancer patients be offered elderly-specific trials? Results of a pooled analysis from the North Central Cancer Treatment Group. J Clin Oncol 23: 9113-9.

13. Camidge DR, Bang YJ, Kwak EL (2012) Activity and safety of crizotinib in patients with ALK-positive non-small-cell lung cancer: updated results from a phase 1 study. Lancet Oncol 13: 1011-9.

14. Wheler JJ, Tsimberidou AM, Falchook GS (2013) Combining erlotinib and cetuximab is associated with activity in patients with non-small cell lung cancer (including squamous cell carcinomas) and wild-type EGFR or resistant mutations. Mol Cancer Ther 12: 2167-75.

15. Wang HP, Zhang L, Wang YX (2011) Phase I trial of icotinib, a novel epidermal growth factor receptor tyrosine kinase inhibitor, in Chinese patients with non-small cell lung cancer. Chin Med J (Engl) 124: 1933.

16. Garon EB, Rizvi NA, Hui R (2015) Pembrolizumab for the treatment of non-small-cell lung cancer. N Engl J Med 372: 2018-28.

17. Goldman JW, Laux I, Chai F (2012) Phase 1 dose-escalation trial evaluating the combination of the selective MET (mesenchymal-epithelial transition factor) inhibitor tivantinib (ARQ 197) plus erlotinib. Cancer 118: 5903-11. 